\title{
A NOVEL CARBOXYLESTERASE FROM ASPERGILLUS NIGER AND ITS HYDROLYSIS OF SUCCINIMIDE ESTERS
}

\author{
by \\ LI XIAOMING ${ }^{1)}$ and KLAUS BREDDAM ${ }^{2)}$ \\ ${ }^{1)}$ Carlsberg Research Laboratory, Gamle Carlsberg Vej 10, \\ DK-2500 Copenhagen Valby \\ ${ }^{2)}$ Department of Chemistry, Carlsberg Laboratory, \\ Gamle Carlsberg Vej 10, DK-2500 Copenhagen Valby
}

Keywords: Carboxylesterase, succinimide ester, Aspergillus niger, kinetics

\begin{abstract}
A novel carboxylesterase (EC 3.1.1.1) from Aspergillus niger has been purified 1400 -fold by ammonium sulphate fractionation, ion exchange chromatography, hydrophobic interaction chromatography and gel filtration. The enzyme consisted of two identical subunits, each with a molecular weight of 60,000 . The isoelectric point was 4.5 . The optimal $\mathrm{pH}$ for the hydrolysis of cinnamic acid ethyl ester and 2-furylacryloyl N-hydroxy succinimide ester was between 5 and 7 . The enzyme, which had no lipase activity, catalyzed the hydrolysis of activated ester substrates where the alcohol moiety was $\mathrm{N}$-hydroxysuccinimide, $\mathrm{p}$-nitrophenol and phenol as well as, with lower rates, unactivated esters like ethyl and benzyl esters. The enzyme exhibited a preference for substrates with an acyl moiety containing an aryl group. The enzyme was inhibited by PMSF but not by $\mathrm{Hg}^{2}+$ and EDTA. It is classified as a serine carboxylesterase.
\end{abstract}

\section{INTRODUCTION}

Carboxyl ester hydrolases (EC 3.1.1.-), which catalyze the hydrolysis of ester bonds, are widely distributed in nature. Based on their hydrolytic specificities, these enzymes may be divided into carboxylesterases (EC 3.1.1.1), arylesterases (EC 3.1.1.2) and lipases (EC 3.1.1.3). Lipases hydrolyse triacyl-glycerols and a number of other esters, participating in hydrolysis reactions at the water/fat interface. Arylesterases preferentially cleave aromatic esters, such as esters of phenol, naphthol and indole (4). Carboxylesterases, which are rather unspecific, catalyze the hydrolysis of ester bonds, where both the alcohol moiety and the acid moiety may be aliphatic as well as aromatic $(3,5,11,14,18,19)$.

Carboxylesterases are involved in a number of biotransformations: hydrolysis of xenobiotic esters, activation of prodrugs, and metabolism of extraneous compounds. Some blood esterases

Abbreviations: $\mathrm{Ac}=$ acetyl; $\mathrm{Bz}=$ benzoyl; $\mathrm{Bzl}=$ benzyl; $\mathrm{Caps}=3$-(cyclohexylamino)-1-propanesulfonic acid; Ches $=2(\mathrm{~N}$-cyclohexylamino)ethane sulfonic acid; $\mathrm{Cin}=$ cinnamoyl $; \quad \mathrm{DMF}=\mathrm{N}, \mathrm{N}$-dimethylformamide; $\mathrm{DMSO}=$ dimethylsulfoxide $;$ EDTA $=$ ethylenediamine tetraacetic acid; $\mathrm{Et}=$ ethyl; $\mathrm{Fa}=$ furylacryloyl; Hepes $=\mathrm{N}$-2-hydroxyethylpiperazine N'-2-ethanesulfonic acid; Hex $=$ hexanoyl; HPLC $=$ high performance liquid chromatography; $\mathrm{Me}=$ methyl; $\mathrm{Mes}=2-(\mathrm{N}$-morpholino $)$ ethanesulfonic acid; $\mathrm{Ph}=$ phenyl; $\mathrm{PMSF}=$ phenylmethylsulfonyl fluoride $\operatorname{Pr}=$ propionyl; Oct $=$ octanoyl; $\mathrm{ONp}=$ p-nitrophenoxy; $\mathrm{ONSu}=$ succinimidooxy; $\mathrm{SDS}=$ sodium dodecyl sulfate; $\mathrm{Z}=$ carbobenzoxy. 
have been found to hydrolyse ester drugs (17). In insects, a carboxylesterase has been found to be involved in the inactivation of juvenile hormone (27); administration of certain carboxylesterase inhibitors to pupae of the tobacco hornworm diminished its inactivation (2). In plants, carboxylesterases may be responsible for the hydrolysis of certain bitter tasting compounds and may thus play a role in providing flavors which attract animals to feed on the fruits. The carboxylesterases from apples have been found to hydrolyze substrates such as ethyl, propyl, pentyl and hexyl acetate (8). Carboxylesterases in microorganisms may be involved in chemotaxis which permits microorganisms to reach food sources by catalyzing demethylation and hence, activation of membrane-bound proteins capable of binding sugars and amino acids (1).

Mammalian carboxylesterases from liver (3, $11,14,15)$, kidney (6), pancreas (19), brain (12), and skin (23) have been studied. Those from liver are the best characterized; they are trimers consisting of three identical subunits with a molecular weight of 60,000 . Although carboxylesterases have been detected in microorganisms, only a single one has been isolated and to some extent described (5). In recent years, carboxylesterases have been used for the synthesis of a number of esters: transesterifications of methyl and ethyl esters of acrylic and methacrylic acids (25) and of $\mathrm{N}$-carbobenzoxy-L-tyrosine p-nitrophenol ester (22) have been reported.

We here describe the isolation and characterisation of an extracellular carboxylesterase (EC 3.1.1.1) from Aspergillus niger.

\section{MATERIALS AND METHODS}

\subsection{Materials}

Palatase A, a crude extract obtained by fermentation with Aspergillus niger, chymotrypsin and subtilisin A were from Novo Industri, Denmark. Pronase, lipase VI and VII were from Sigma, USA. Carboxypeptidase Y was a laboratory preparation (13). Mes, Hepes, ethyl cinnamate, phenyl acetate as well as p-nitrophenyl esters were from Sigma, USA. Z-Ala-OSu and Z-Val-OSu were from Bachem, Switzerland. Chromatographic materials were from Pharmacia, Sweden. Benzyl cinnamate and ethyl ben- zoate were from Aldrich-Chemie, West Germany. Z-ONSu, t-cinnamic acid and 3-phenylpropionic acid were from Fluka Chemie AG, Switzerland. p-Nitrophenyl cinnamate, phenyl cinnamate and cinnamanilide was prepared in the following way: 0.01 mole cinnamic acid and 0.01 mole 4-nitrophenol, phenol, aniline or $\mathrm{N}$ hydroxy-succinimide were dissolved in $20 \mathrm{ml}$ tetrahydrofuran and cooled to $0^{\circ} \mathrm{C} .2 .06 \mathrm{~g} \mathrm{~N}, \mathrm{~N}$ dicyclohexylcarbodiimide was added and left at $0{ }^{\circ} \mathrm{C}$ for 2 hours, and then at $25^{\circ} \mathrm{C}$ for one hour. The reaction mixture was filtered on a sintered glass funnel to remove the precipitate. The filtrate was evaporated to dryness and crystallization was achieved from ether/benzin (p-nitrophenol cinnamate) or ethanol/water (phenyl cinnamate and cinnamanilide). The melting points of different ester compounds were determined: phenyl cinnamate, $75.5-76.5^{\circ} \mathrm{C}$; p-nitrophenyl cinnamate, $145-146{ }^{\circ} \mathrm{C}$; cinnamanilide, $150-151^{\circ} \mathrm{C}$; $\mathrm{Cin}-\mathrm{ONSu}, 178-179{ }^{\circ} \mathrm{C}$.

\subsection{Methods}

\subsubsection{Enzyme assays}

During purification the enzymatic activity at $25^{\circ} \mathrm{C}$ towards $\mathrm{Fa}$-ONSu was determined spectrophotometrically at $337 \mathrm{~nm}$ using a Perkin-Elmer Lambda 17. The following routine assay mixture was used: $10 \mu \mathrm{l} 8 \mathrm{~mm}$ Fa-ONSu, dissolved in methanol, was added to $980 \mu 10.05 \mathrm{M} \mathrm{Mes,} 1 \mathrm{mM}$ EDTA, pH 6.3, followed by addition of $10 \mu \mathrm{l} \mathrm{en-}$ zyme solution. $\mathrm{A} \Delta \mathrm{E}_{337}=21200 \mathrm{M}^{-1} \mathrm{CM}^{-1}$ was determined.

The activity at $25^{\circ} \mathrm{C}$ towards various other substrates was assayed by using the following assay mixture: $5 \mu 125 \mathrm{~mm}$ substrate in DMSO was added to $985 \mu$ l of the same buffer as described above, followed by addition of $10 \mu$ l enzyme solution. The following wavelengths and extinction coefficients were used: $\Delta \mathrm{E}_{305}=7600 \mathrm{M}^{-1} \cdot \mathrm{CM}^{-1}$ (Cin-OEt), $\Delta \mathrm{E}_{270}=2500 \mathrm{M}^{-1} \cdot \mathrm{CM}^{-1}(\mathrm{Z}-\mathrm{ONSu})$, $\Delta \mathrm{E}_{310}=15000 \mathrm{M}^{-1} \cdot \mathrm{CM}^{-1}$ (Cin-ONSu), $\Delta \mathrm{E}_{260}=$ $1400 \mathrm{M}^{-1} \cdot \mathrm{CM}^{-1}(\mathrm{Cin}-\mathrm{OBzl}), \Delta \mathrm{E}_{300}=16000 \mathrm{M}^{-1}$ $\cdot \mathrm{CM}^{-1}$ (Cin-OPh), $\Delta \mathrm{E}_{348}=5200 \mathrm{M}^{-1} \cdot \mathrm{CM}^{-1}$ (Cin-ONp), and $\Delta \mathrm{E}_{348}=5200 \mathrm{M}^{-1} \cdot \mathrm{CM}^{-1}$ (p-nitrophenyl esters) and $\Delta \mathrm{E}_{270}=1500 \mathrm{M}^{-1} \cdot \mathrm{CM}^{-1}$ (phenyl acetate) were used. One activity unit was defined as the amount of enzyme necessary to break down one micromole of substrate per 
minute.

Lipase activity was determined at $30^{\circ} \mathrm{C}$ by conventional titration using tributyrin as a substrate. Substrate emulsion was prepared by blending $15 \mathrm{ml}$ tributyrin (Merck), $50 \mathrm{ml}$ emulsi-

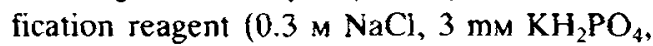
$54 \%$ glycerol (v/v) and $0.6 \%$ Gum Arabic) and $235 \mathrm{ml}$ deionized water. The assay procedure was performed as follows: $10 \mathrm{ml}$ substrate was preheated for at least 3 minutes at $30^{\circ} \mathrm{C}$, followed by the addition of $100 \mu$ l of enzyme solution $(0.7 \mathrm{mg} / \mathrm{ml})$. A control was performed using a known lipase. The butyric acid liberated was titrated with $0.05 \mathrm{~m} \mathrm{NaOH}$ by means of the $\mathrm{pH}$ stat technique.

The protein concentration was determined spectrophotometrically at $280 \mathrm{~nm}$ using $\mathrm{A}_{280}$ $(1 \%)=18.7$, derived from the amino acid composition and carbohydrate content of the pure enzyme.

\subsubsection{Purification}

1 liter Palatase $A$ was diluted with 2 liters of water followed by addition of ammonium sulfate to $45 \%$ saturation. Continuous stirring was maintained at $4{ }^{\circ} \mathrm{C}$ for 12 hours. The precipitate was removed by centrifugation and to the supernatant was added ammonium sulfate to $60 \%$ saturation. After 16 hours of stirring at $4{ }^{\circ} \mathrm{C}$, the suspension was centrifuged. The precipitate was dissolved in water and diafiltrated against 0.02 м sodium acetate, $\mathrm{pH} 4.3$ using a Pellicon system from Millipore. The sample was applied to a CM-52 cellulose column $(10 \times 25 \mathrm{~cm})$, equilibrated with the same buffer, and the column was washed with $0.02 \mathrm{M}$ sodium acetate $\mathrm{pH} 4.3$ until $A_{280}$ of the eluate was below 0.2 . The enzyme was eluted by applying a $0-0.3 \mathrm{M}$ sodium chloride gradient in the same buffer. The fractions containing activity were pooled, concentrated by ultrafiltration as described above and adjusted to $1 \mathrm{M}$ ammonium sulphate. This concentrate was applied to an Octyl-Sepharose coiumn $(5 \times 20 \mathrm{~cm})$ and a Phenyl-Sepharose column $(2.6$ $\times 20 \mathrm{~cm}$ ), connected in this order in series and equilibrated with $0.02 \mathrm{~m}$ sodium acetate, $1 \mathrm{~m}$ ammonium sulfate $\mathrm{pH} 4.3$. The enzyme passed through the Octyl-Sepharose column and bound to the Phenyl-Sepharose column. One bed volume of the equilibrating buffer was used to wash the two columns and after disconnecting the two columns the Phenyl-Sepharose column was washed with another two bed volumes of $0.1 \mathrm{M}$ ammonium sulphate, $0.02 \mathrm{~m}$ sodium acetate $\mathrm{pH} 4.3$. The enzyme was eluted from the Phenyl-Sepharose column with $20 \mathrm{~mm}$ 3-phenylpropionic acid in $0.02 \mathrm{M}$ sodium acetate, at the same $\mathrm{pH}$. The pooled fractions from Phenyl-Sepharose column was concentrated to $6 \mathrm{ml}$ by ultrafiltration using an Amicon cell. The $\mathrm{pH}$ of the sample was adjusted to 6.5 with $0.5 \mathrm{~m}$ phosphate buffer ( $\mathrm{pH} 6.5$ ) and applied to a Sephadex G-150 column (2.6X $90 \mathrm{~cm}$ ), equilibrated with $50 \mathrm{~mm} \mathrm{KH}_{2} \mathrm{PO}_{4}, 0.1 \mathrm{M}$ $\mathrm{NaCl}, \mathrm{pH} 6.5$.

\subsubsection{Homogeneity, isoelectric point and molecular weight}

The purity and molecular weight of the isolated enzyme with or without reduction with dithiothreitol was determined by SDS-polyacrylamide gel electrophoresis using a $10-15 \%$ gradient gel and the Pharmacia Phast system GE-2/4LS. Coomassie blue was used for staining. The molecular weight of the native enzyme was determined by gel filtration on Sephacyl S-300 HR. The column $(1.6 \times 90 \mathrm{~cm})$ was equilibrated with 0.05 mM $\mathrm{KH}_{2} \mathrm{PO}_{4}, 0.1 \mathrm{M} \mathrm{NaCl}, \mathrm{pH} 7.5$, and calibrated with standard proteins.

The isoelectric point of the pure enzyme was determined by focusing in a polyacrylamide gel (1 mm thick, 10\% glycerol slabs, Phamlyte interval 3-10 and 4.15-5.85). Coomassie blue was used for staining. The isoelectric focusing was carried out in a Pharmacia gel electrophoresis apparatus GE-2/4 LS.

\subsubsection{Chemical composition}

Samples were hydrolysed in $6 \mathrm{M} \mathrm{HCl}$ at $110^{\circ} \mathrm{C}$ in vacuo for 24,48 and 72 hours (21). The hydrolysates were analyzed on Durrum D-500 amino acid analyzer. Tryptophan content was determined by the procedure of GoODwIN and MorTon (9). Half-cystine was determined as cysteic acid after performic acid oxidation (10). The carbohydrate content was determined by the method of Dubors (7), using glucose as a standard. 


\subsubsection{Stability}

The stability of the enzyme was estimated by incubating $25 \mu \mathrm{l}$ enzyme $(0.7 \mathrm{mg} / \mathrm{ml})$ in $475 \mu \mathrm{l}$ 0.05 м Mes, 1 mм EDTA pH 6.3 at $22^{\circ} \mathrm{C}, 30^{\circ} \mathrm{C}$, $40{ }^{\circ} \mathrm{C}$ and $50{ }^{\circ} \mathrm{C}$. Aliquots were taken for assay using Fa-ONSu as substrate (see section 2.2.1). The stability at different $\mathrm{pH}$ values was determined at $25^{\circ} \mathrm{C}$ by incubating $25 \mu \mathrm{l}$ enzyme (1.4 $\mathrm{mg} / \mathrm{ml}$ ) in $475 \mu \mathrm{l} 50 \mathrm{~mm}$ buffer (formic acid, $\mathrm{pH}$ 3.3-4.2; acetic acid, $\mathrm{pH} 4.3-5.4$; Mes, $\mathrm{pH}$ 5.5-7.0; Hepes, pH 7.1-8.0; Ches, pH 8.1-8.8; Caps, pH 9.0-11). Aliquots were taken for assay at different times. The activity towards ethyl cinnamate was assayed using the procedure described in section 2.2.1.

The influence of organic solvents on the activity was assayed in the following way: to $980 \mu \mathrm{l}$ assay buffer (50 mм Mes, 1 mм EDTA, pH 6.3), containing $50 \%, 25 \%, 10 \%$ or $5 \%$ of different organic solvents (dioxane, DMF, EtOH, DMSO and $\mathrm{MeOH}$ ) was added $10 \mu$ l of enzyme $(0.118 \mathrm{mg} / \mathrm{ml})$ and $10 \mu \mathrm{l} 8 \mathrm{~mm} \mathrm{Fa}-\mathrm{ONSu}$ in DMSO.

\subsubsection{Enzymatic properties}

$\mathrm{K}_{\mathrm{m}}$ and $\mathrm{k}_{\text {cat }}$ values were determined graphically from Lineweaver-Burk plots. $25 \% \mathrm{DMSO}$ was included in the assay buffer. The $\mathrm{pH}$ dependence was determined using the buffer system described in the previous section. Ethyl cinnamate and $\mathrm{Fa}$-ONSu were used as substrates. The assay was performed as follows: $5 \mu 125 \mathrm{~mm}$ ethyl cinnamate in DMSO was added to $985 \mu \mathrm{l}$ $50 \mathrm{~mm}$ buffer (section 2.2.5), followed by addi- tion of $10 \mu$ l enzyme solution $(0.24 \mathrm{mg} / \mathrm{ml})$; with Fa-ONSu, $10 \mu 18 \mathrm{~mm}$ substrate in DMSO was added to $980 \mu \mathrm{l} 50 \mathrm{~mm}$ buffer, followed by addition of $10 \mu$ l enzyme solution $0.031 \mathrm{mg} / \mathrm{ml}$ ). The effect of PMSF was investigated by incubating the enzyme $(0.04 \mathrm{mg} / \mathrm{ml})$ in $500 \mu 150 \mathrm{~mm}$ Mes, $1 \mathrm{~mm}$ EDTA, pH 6.3, containing 0.1 mM PMSF. The activity towards Fa-ONSu (see section 2.2.1) was assayed as function of time.

The effects of mercuric ions on the enzymatic activity was investigated in the following way: 10 $\mu$ l enzyme solution $(0.024 \mathrm{mg} / \mathrm{ml})$ was added to a cuvette containing $980 \mu 150 \mathrm{~mm}$ Mes pH 6.3, 50 $\mu \mathrm{M} \mathrm{HgCl}$, and after incubation for 20 minutes, the activity was measured by addition of $10 \mu \mathrm{l} 4$ mM Fa-ONSu in DMSO. The effects of salt and EDTA on the enzymatic activity was investigated in $50 \mathrm{~mm}$ sodium acetate, $\mathrm{pH} 4.5$ with or without EDTA and $\mathrm{NaCl}$. The activity towards $\mathrm{Fa}-\mathrm{ONSu}$ was determined.

\section{RESULTS}

A number of commercially available enzyme preparations obtained by fermentation with fungi were found to hydrolyse 2-furylacryloyl$\mathrm{N}$-hydroxy-succinimide ester (Fa-ONSu). Enzymatic hydrolysis of such activated esters, which could be monitored spectrophotometrically at $337 \mathrm{~nm}$, have not previously been reported. It was initially believed that this activity was due to a proteolytic enzyme or a lipase. However, even at high concentrations $(1 \mathrm{mg} / \mathrm{ml})$, the enzymes chymotrypsin, subtilisin A, carboxypeptidase $\mathrm{Y}$, pronase as well as lipases VI and VII,

Table I. Purification of carboxylesterase

$\mathrm{Fa}-\mathrm{ONSu}$

\begin{tabular}{lccccc} 
Purification & & & & & \\
step & $\mathrm{ml}$ & $\mathrm{A}_{280}$ & $\mathrm{U} / \mathrm{ml}$ & $\mathrm{U}_{\text {total }}$ & $\mathrm{U} / \mathrm{mg}$ \\
\hline Crude extract & 1000 & 210 & 6.66 & 6600 & 0.058 \\
$\left(\mathrm{NH}_{4}\right)_{2} \mathrm{SO}_{4}(45 \%)$ & 3300 & 73 & 2.19 & 7300 & 0.056 \\
$\left(\mathrm{NH}_{4}\right)_{2} \mathrm{SO}_{4}(60 \%)$ & 2000 & 18 & 2.37 & 4700 & 0.25 \\
$\mathrm{CM}^{-52}$ & 1100 & 2.1 & 3.16 & 3500 & 2.8 \\
Octyl/Phenyl-Sep. & 550 & 0.18 & 3.0 & 1700 & 32 \\
G-150 & 32 & 0.70 & 30.9 & 990 & 82 \\
\hline
\end{tabular}

The assay was performed as described in section 2.1.1. 
were unable to hydrolyse Fa-ONSu. This appeared to exclude the possibility of a protease or a lipase. A carboxylesterase was then considered the most probable. To establish the origin of this activity the enzyme was isolated (Table I).

It was not possible to precipitate the enzyme in the crude extract with ammonium sulfate, possibly due to the high content of glycerol in the preparation, added for stabilization. However, after a three-fold dilution in water, an ammonium sulphate fractionation $(45 \%-60 \%)$ could be performed. In the ion exchange chromatography, we found that the capacity of the resin decreased with $\mathrm{pH}$ in the range 4-5. In hydrophobic interaction chromatography, a stronger binding to Octyl-Sepharose as compared with Phenyl-Sepharose would be predicted. However, with the present enzyme the opposite was the case suggesting that the binding to the Phe-

Table II. Amino acid composition of carboxylesterase

\begin{tabular}{lc}
\hline Amino acid & $\begin{array}{c}\text { Residues per } \\
\text { subunit }\end{array}$ \\
\hline Asp & 66 \\
Thr & 31 \\
Ser & 35 \\
Glu & 42 \\
Pro & 35 \\
Gly & 47 \\
Ala & 43 \\
Val & 28 \\
Met & 6 \\
Ile & 18 \\
Leu & 29 \\
Tyr & 30 \\
Phe & 22 \\
His & 10 \\
Lys & 15 \\
Arg & 22 \\
Cys & 8 \\
Trp & 12 \\
Carbohydrate & $4 \%$ \\
\hline
\end{tabular}

The experimental values were based on the amino acid analysis after hydrolysis by $6 \mathrm{M} \mathrm{HCl}$ for 24,48 , and 72 hours (21). The values of serine and threonine were determined by extrapolation to zero time. Cysteine was determined as cysteic acid after performic acid oxidation (10). Tryptophan was determined spectrophotometrically by the method of Goodwin and Morton (9). The carbohydrate content was determined by the method of Dubois (7) et al.
nyl-Sepharose was not purely hydrophobic by nature. This was confirmed by the inability of buffer without ammonium sulphate to elute more than $30 \%$ of enzyme; the major part remained on the column, and could be eluted with $40 \%$ ethyleneglycol, apparently due to a different type of interaction. By including $20 \mathrm{~mm}$ 3-phenylpropionic acid in the buffer $60 \%$ the of enzyme was eluted, suggesting that this resin to some extent behaves as an affinity resin and 3-phenylpropionic acid competes with the immobilized ligand.

The isolated enzyme showed a single band on SDS-polyacrylamide gel electrophoresis with a mobility corresponding to a molecular weight of 60,000 both in the presence and in the absence of dithiothreitol. The molecular weight of the native enzyme was 100,000 as determined by gel filtration (Sephacryl S-300 HR) indicating that the enzyme is a dimer consisting of two subunits each of molecular weights 60,000 . The enzyme had an isoelectric point of 4.5. This was in good agreement with the strong $\mathrm{pH}$ dependence of its binding to $\mathrm{CM}-52$ cellulose in the $\mathrm{pH}$ range 4.0 5.0 (see above). The amino acid composition of the carboxylesterase is listed in Table II.

At pH 6.3 the enzyme was stable at $22^{\circ} \mathrm{C}$ and $30{ }^{\circ} \mathrm{C}$ over 24 hours. At $40^{\circ} \mathrm{C}$ and $50^{\circ} \mathrm{C}$ the activity was lost with half-lives of 23 hours and 1.5 hour. At $22{ }^{\circ} \mathrm{C}$ the enzyme was stable over 24 hours at $\mathrm{pH} 3.2$ and 6.3 whereas at $\mathrm{pH} 9.5$ the activity was lost with a half life of approximately 12 hours.

Table III. Effects of organic solvents on the enzymatic activity

\begin{tabular}{lcccc}
\hline Solvent & \multicolumn{4}{c}{ Concentration of solvent in assay mixture } \\
\cline { 2 - 5 } & $50 \%$ & $25 \%$ & $10 \%$ & $5 \%$ \\
\hline Dioxan & 0 & 2 & 17 & 29 \\
DMF & 0 & 20 & 49 & 59 \\
EtOH & 0 & 15 & 56 & 61 \\
DMSO & 0 & 41 & 63 & 67 \\
MeOH & 0 & 48 & 96 & 110 \\
\hline
\end{tabular}

The activity (U/mg) was determined as described previously. The following assay procedure was used: to $980 \mu \mathrm{l}, 50 \mathrm{~mm}$ Mes, $1 \mathrm{~mm}$ EDTA, pH 6.3, containing $50 \%, 25 \%, 10 \%$ or $5 \%$ of different organic solvents was added $10 \mu 18 \mathrm{~mm}$ Fa-ONSu in DMSO, followed by addition of $10 \mu \mathrm{l}$ enzyme solution $(0.118 \mathrm{mg} / \mathrm{ml}$ ) (see section 2.2.5). 
The substrates for the isolated enzyme were generally only slightly soluble in water and therefore had to be added to the aqueous buffer from a solution in a water-miscible solvent. The influence of such solvents on the activity of the enzyme was consequently studied (Table III). All the solvents tested abolished the enzymatic activity at $50 \%$ and at lower concentrations the inhibition was in the following decreasing order: dioxane $>$ DMF $>$ EtOH $>$ DMSO $>\mathrm{MeOH}$.

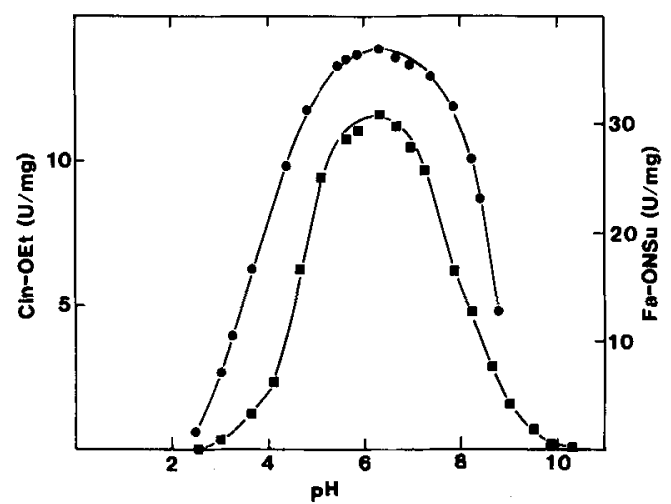

Figure 1. The influence of $\mathrm{pH}$ on the activity of the carboxylesterase on the hydrolysis of Cin-OEt ( $(\boldsymbol{)})$ and Fa-ONSu (॰). The following conditions were used: 980 $\mu \mathrm{l} 50 \mathrm{~mm}$ buffer, $1 \mathrm{~mm}$ EDTA $+10 \mu l 8 \mathrm{~mm}$ Fa-ONSu in DMSO (or $5 \mu 125$ mм Cin-OEt in DMSO) $+10 \mu 1$ enzyme. For details see section 2.2.1.

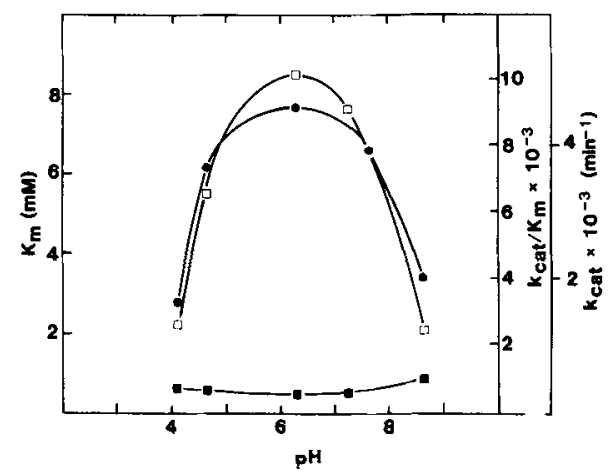

Figure 2. The influence of $\mathrm{pH}$ on the kinetic parameters for the hydrolysis of Cin-OEt, $\mathrm{K}_{\mathrm{m}} \boldsymbol{\bullet}, \mathrm{k}_{\mathrm{cat}} \bullet, \mathrm{k}_{\mathrm{cat}} / \mathrm{K}_{\mathrm{m}} \square$. The following conditions were used: $985 \mu \mathrm{l} 50 \mathrm{~mm}$ buffer, $1 \mathrm{~mm}$ EDTA + $5 \mu$ l Cin-OEt (7.5-50 mm in DMSO) $+10 \mu$ l enzyme solution. The values were determined from Lineweaver-Burke plots. For details see section 2.2.1.
The pH optima for the hydrolysis of ethyl cinnamate and Fa-ONSu were between 5.5 and 7.0 (Figure 1). The $\mathrm{K}_{\mathrm{m}}$ value was found to be independent of $\mathrm{pH}$ while $\mathrm{k}_{\mathrm{car}}$ appeared to be dependent on the deprotonation of a group with a $\mathrm{pK}_{\mathrm{a}}$ value around 5 and on the protonation of a group with a $\mathrm{pK}_{\mathrm{a}}$ value around 8 (Figure 2 ). The enzyme did not hydrolyse tributyrin, strongly suggesting that it is not a lipase. However, it hydrolysed a number of esters of cinnamic acid (Table IV): the activated $\mathrm{N}$-hydroxy succinimide,

Table IV. Carboxylesterase catalyzed hydrolysis of ester substrates: the influence of the alcohol moiety

\begin{tabular}{lccc}
\hline Substrate & $\begin{array}{c}\mathbf{k}_{\mathrm{cat}} \\
\left(\mathrm{min}^{-1}\right)\end{array}$ & $\begin{array}{c}\mathbf{K}_{\mathrm{m}} \\
(\mathrm{mM})\end{array}$ & $\begin{array}{c}\mathbf{k}_{\mathrm{cat}} / \mathrm{K}_{\mathrm{m}} \\
\left(\mathrm{min}^{-1} \cdot \mathrm{mm}^{-1}\right)\end{array}$ \\
\hline Cin-ONSu & 23000 & 0.10 & $2.3 \times 10^{5}$ \\
Cin-ONp & 12000 & 0.10 & $1.2 \times 10^{5}$ \\
Cin-OPh & 24000 & 0.25 & $9.6 \times 10^{4}$ \\
Cin-OBzl & 2900 & 0.17 & $1.7 \times 10^{4}$ \\
Cin-OEt & 1100 & 0.67 & $1.6 \times 10^{3}$ \\
Cin-NHPh & - & - & $<<10$ \\
\hline
\end{tabular}

The assays were carried out by using $740 \mu 150 \mathrm{~mm}$ Mes, $1 \mathrm{~mm}$ EDTA, pH 6.3, 240 $\mu \mathrm{I}$ DMSO $(25 \%)$ and $10 \mu \mathrm{l}$ of substrate in DMSO, followed by addition of $10 \mu \mathrm{l}$ enzyme solution. The activity measurements are described in 2.2.1.

p-nitrophenyl and phenyl esters were hydrolysed with the highest $k_{c a t} / K_{m}$, whereas the ethyl and benzyl esters were hydrolysed with significantly lower values. A comparison of the kinetic parameters for the hydrolysis of the structurally similar phenyl and benzyl esters suggest that the different $k_{c a t} / K_{m}$ values between the activated and unactivated ester primarily is due to an effect on $k_{\text {cat }}$. The higher $k_{\text {cat }} / K_{m}$ for the hydrolysis of the benzyl ester as compared with the equally activated ethyl ester, on the other hand, is primarily due to a difference in $\mathrm{K}_{\mathrm{m}}$. It should be noted that the anilide of cinnamic acid is not hydrolysed by the enzyme suggesting that the enzyme is specific for ester bonds and does not hydrolyse amide bonds.

The influence of the structure of the acyl component on the kinetic parameters was investigated with a series of aromatic $\mathrm{N}$-hydroxy-succinimides and p-nitrophenyl esters of different aliphatic acids. Among the latter $\mathrm{k}_{\mathrm{cat}} / \mathrm{K}_{\mathrm{m}}$ increased with 
the chain length and reached the highest value with the p-nitrophenyl ester of octanoic acid. The activity towards substrates of acids with longer chains could not be determined due to lack of solubility in the assay medium (25\% DMSO). However, the $k_{\text {cat }} / \mathrm{K}_{\mathrm{m}}$ values for hydrolysis of these substrates are low relative to that of the p-nitrophenyl ester of cinnamic acid, containing an aromatic group, and this is primarily due to an effect on $\mathrm{k}_{\text {cat }}$. The preference for an acyl moiety containing an aromatic group is also apparent from the high $\mathrm{k}_{\mathrm{ca}} / \mathrm{K}_{\mathrm{m}}$ values for the hydrolysis of various aromatic succinimide esters in Table V.

Table V. Carboxylesterase catalyzed hydrolysis of ester substrates: the influence of the acyl moiety

\begin{tabular}{lccc}
\hline Substrate & $\begin{array}{c}\mathrm{k}_{\text {cat }} \\
\left(\mathrm{min}^{-1}\right)\end{array}$ & $\begin{array}{c}\mathrm{K}_{\mathrm{m}} \\
(\mathrm{KM})\end{array}$ & $\begin{array}{c}\mathrm{k}_{\text {cat }} / \mathrm{K}_{\mathrm{m}} \\
\left(\mathrm{min}^{-1} \cdot \mathrm{mm}^{-1}\right)\end{array}$ \\
\hline Cin-ONSu & 23000 & 0.1 & $2.3 \times 10^{5}$ \\
Fa-ONSu & 9300 & 0.06 & $1.6 \times 10^{5}$ \\
Z-ONSu & 4800 & 0.04 & $1.2 \times 10^{5}$ \\
Z-Ala-ONSu & 25000 & 0.75 & $3.3 \times 10^{4}$ \\
Z-Val-ONSu & - & - & $<<1$ \\
& & & \\
Ac-ONp & 200 & 0.33 & $6.1 \times 10^{2}$ \\
Pr-ONp & 330 & 0.37 & $8.9 \times 10^{2}$ \\
Hex-ONp & 670 & 0.24 & $2.8 \times 10^{3}$ \\
Oct-ONp & 500 & 0.04 & $1.3 \times 10^{4}$ \\
\hline
\end{tabular}

The assays were carried out by using $740 \mu 150 \mathrm{~mm}$ Mes, $1 \mathrm{~mm}$ EDTA, pH 6.3, 240 $\mu \mathrm{l}$ DMSO (25\%) and $10 \mu \mathrm{l}$ of substrate in DMSO, followed by addition of $10 \mu \mathrm{l}$ enzyme solution. The activity measurements are described in section 2.2.1.

Other experiments showed that the enzyme did not catalyze the hydrolysis of simple esters, e.g., ethyl, butyl and propyl esters of octanoic acid.

The enzyme was completely inhibited by PMSF within 30 minutes. However, $50 \mu \mathrm{m}$ of mercuric ions only decreased the activity by $20 \%$ and $\mathrm{Ca}^{2+}$ and EDTA had no influence on the activity.

\section{DISCUSSION}

Carboxylesterases have been found in a wide variety of higher plants (16) and animals $(11,14)$, while only one such enzyme has been described from a microorganism (5). The present enzyme from Aspergillus niger was inhibited by PMSF but not by mercuric ions and EDTA. Inhibition by PMSF is indicative of the involvement of a seryl residue and an acyl-enzyme intermediate in the catalytic mechanism. Similar results have been obtained with carboxylesterases from mammalian liver (15).

Most carboxylesterases thus far described exhibit optimal activity around $\mathrm{pH} 8(5,26)$. However, JUNGE has reported that an isoenzyme of pig-liver esterase had a $\mathrm{pH}$ optima between 6-7 (15). In our case, the optimal $\mathrm{pH}$ for the hydrolysis of $\mathrm{Fa}-\mathrm{ONSu}$ and ethyl cinnamate was found in the $\mathrm{pH}$ range of 5.5-7. The enzyme is a dimer with two identical subunits, each with a molecular weight of 60,000 as opposed to the carboxylesterases from mammalian liver which are trimers with three identical subunits of molecular weights of $60,000(3,14,26)$.

The enzyme hydrolyses ester substrates of the type $\mathrm{R}_{1}$-COO- $\mathrm{R}_{2}$ with a preference for those with activated leaving groups $\left(\mathrm{R}_{2}\right)$, i.e., $-\mathrm{ONSu}$ $>-\mathrm{ONp}>-\mathrm{OPh}>-\mathrm{OBzl}>-\mathrm{OEt}$. The series of cinnamic acid esters are hydrolysed through the same acyl-enzyme intermediate and since the $\mathrm{k}_{\text {cat }}$ values vary from 1100 to $24,000 \mathrm{~min}^{-1}$, it may be concluded that the acylation step is rate-limiting, at least in the hydrolysis of the two alkyl esters, i.e., Cin-OEt and Cin-OBzl.

It appears that the enzyme exhibits a preference for substrates where both $R_{1}$ and $R_{2}$ contain an aromatic group. Substrates where either of the two groups is aliphataic and the other is aromatic are also hydrolysed. However, when both groups are aliphatic, e.g. the ethyl, butyl and propyl esters of octanoic acid, no hydrolysis was observed. The ability of the enzyme to hydrolyse other than aryl esters exclude a classification as an arylesterase. Classification of the enzyme as a carboxylesterase is the most reasonable although the enzyme exhibits a preference for substrates containing aryl groups.

Among the esterases isolated from other species only those from mammalian liver have been subjected to a similar characterisation with re- 
spect to substrate preference. These enzymes hydrolyse substrates where both $R_{1}$ and $R_{2}$ (see above) are aliphatic in addition to substrates where they are aromatic (15). Since they also hydrolyse the lipase substrate tributyrin (this is also the case with a number of less well characterised carboxylesterases) it is questionable whether they should be classified as carboxylesterases. In any event the enzyme from Aspergillus described here is much more specific.

The possibilites of utilising this enzyme for synthesis of organic compounds, especially by exploiting its activity towards $\mathrm{N}$-ahydroxysuccinimides, which are important intermediates in organic chemistry, have not yet been investigated.

\section{REFERENCES}

1. AdLER, J: How motile bacteria are attracted and repelled by chemical: an approach to neurobiology. Bio. Chem. Hopper-Seyler 368, 163-173 (1987)

2. AJami, A.M: Inhibitors of ester hydrolysis as synergists for biological activity of cecropia juvenile hormone. J. Insect Physiol. 21, 1017 (1975)

3. Arndt, R., E. Heymann, W. Junge, K. Krisch \& H. HollaNDT: Purification and molecular properties of an unspecific carboxylesterase (E1) from ratliver microsomes. Eur. J. Biochem. 36, 120-128 (1973)

4. Augustinsson, K.B: Electrophoretic separation and classification of blood plasma esterases. Nature 181, 1786-1789 (1958)

5. Byrde, R.J.W. \& A.H. Fielding: Studies on the acetylesterase of Sclerotinia laxa. Biochem. J. 61, 3337-3341 (1955)

6. Chow, Y.K. \& D.J. Ecobichon: Characterization of the esterases of guinea-pig liver and kidney. Biochem. Pharmacol. 22, 689-701 (1973)

7. Dúbois, M., K.A. Gilles, J.K. Hamilton, P.A. ReBers \& F. SMITH: Colorimetric method for determination of sugar and related substances. Anal. Chem. 38, 350-356 (1956)

8. Goodenough, P.W. \& T.G. Entwistle: The hydrodynamic properties and kinetic constants with natural substrates of the esterase from Malus pumila fruit. Eur. J. Biochem. 127, 145-149 (1982)

9. Goodwin, T.W. \& R.A. Morton: The spectrophotometric determination of tyrosine and tryptophan in proteins. Biochem. J. 40, 628-632 (1946)

10. HiRs, C.H.W: Determination of cystine as cysteric acid. Meth. Enzymol. 11, 59-62 (1967)
11. Horgan, D.J., J.K. Stoops, E.C. Webb \& B. Zerner: A large-scale purification of pig liver carboxylesterase. Biochemistry. 8, 2000-2006 (1969)

12. Højring, N. \& O. Svensmark: Carboxylesterases of human brain extract, purification and properties of a butyrylesterase. Biochim. Biophys. Acta. 481, 500 (1977)

13. Johansen, J.T., K. Bredpam \& M. Ottesen: Isolation of carboxypeptidase $\mathrm{Y}$ by affinity chromatography. Carlsberg Res. Commun. 41, 1-14 (1976)

14. Junge, W., E. Heymann \& K. KRISch: Human liver carboxylesterase. Purification and molecular properties. Arch. Biochem. \& Biophys. 165, 749-763 (1974)

15. Junge, W. \& E. Heymann: Characterization of the isoenzymes of pig-liver esterase. Eur. J. Biochem. 95, 519-529 (1979)

16. Krell, H.-W. \& H. Sandermann, JR: Purification and properties of a wheat esterase hydrolyzing the plasticizer chemical, bis(2-ethylhexyl)phthalate. Eur. J. Biochem. 143, 57-62 (1984)

17. LA Du, B.N. \& H. SNADY: In: Handbook of Exp. Pharmacology, vol. 28, pt. II (ed. B.B. Brodie and J.R. Gillette), Springer-Verlag, New York, 1971, p.477

18. LeE, S.Y. \& B.H. LeE: Production and characterization of esterase-lipase of Lactobacillus casei subsp. pseudo plantarum LE2. Biotech. \& Appl. Biochem. 11, 552-563 (1989)

19. Lombardo, D: Catalytic properties of human pancreatic carboxylic-ester hydrolase. Biochimica et Biophysica Acta. 700, 75-80 (1982)

20. Matos, J.R., J.B. West \& C.H. Wong: Lipase catalyzed synthesis of peptides. Biotech. Lett. 9,233236 (1987)

21. Moore, S. \& W.H. Stein: Chromatographic determination of amino acid by the use of automatic recording equipment, in: Methods Enzymol. S.P. Colowick \& N.O. Kaplan (ed.) Academic Press, vol.6, pp. 819-831 (1963)

22. Owusu, R.K. \& D.A. Cowan: Biocatalysis in organic solvent systems using thermostable enzymes: esterase-catalyzed transesterification of Z-L-tyrosine p-nitrophenyl ester. Enzyme Microb. Technol. 12, 374-377 (1990)

23. Pannatier, A., B. Testa \& J.C. Etter: Enzymatic hydrolysis by mouse skin homogenates structure metabolism relationships of p-nitro-benzoate esters. Int. J. Pharmaceutics, 8, 167-174 (1981)

24. Schwartz, H.M., S.I. Biedron, M.M. von Holdt \& S. Renm: Plant esterases. Phytochemistry 3, 189200 (1964)

25. Tor, R., Y. Dror \& A. Freeman: Enzymatically catalyzed transesterification of acryl and methacryl monomeric esters. Enzyme Microb. Technol. 12. 
299-304 (1990)

26. Tsujita, T., H. Okuda \& N. Yamasaki: Purification and some properties of carboxylesterase of rat adipose. Biochim. Biophys. Acta. 715, 181 (1982)
27. WHITE, A.F: Metabolism of the juvenile hormone analogue methylfarnesoate 10,11-epoxide in 2 insect species. Life Sci. part II, Biochem. Gen. Mol. Biol. 11, 201-210 (1972) 